研究論文

\title{
静圧軸受け機構を利用した高速・精密位置決め用エアサーボテーブルの開発*
}

\author{
張 志 城**, 香 川 利 春** \\ 藤 田 壽 憲**, 大 隅 雄三郎***
}

\section{Development of Pneumatic Servo Table for Accurate and Speedy Positioning Mounted with Externally Pressurized Air Bearings}

\author{
Jiseong JANG, Toshiharu KAGAWA, Toshinori FUJUTA, Yuzaburo OHSUMI
}

In pneumatically actuated servo mechanisms, accurate and speedy positioning as an electric servo has been regarded as being difficult because of the disturbance caused by fluctuations in the friction force and air compressibility been carried out. Therefore, studies on positioning in a pneumatic servo have concentrated regarding the compensation of nonlinearity according to air compressibility and friction force. In this study, an servo table mounted with externally pressurized air bearings is proposed to compensate for the friction force that has a serious effect on the accurate positioning in the vicinity of the reference displacement. The table is driven by two servo valves operating at nearly $100 \mathrm{~Hz}$ for speedy positioning. As a result, this study was able to confirm that the friction force on this table was nearly zero, therefore, $10 \mu \mathrm{m}$ accuracy could be obtained easily by using this table at positioning and in the case of Ref. $2 \mathrm{~mm}$, the table was converged to it in $16 \mathrm{~ms}$ within an accuracy of $\pm 10 \mu \mathrm{m}$.

Keywords: accurate positioning, air bearing, compensation of friction force

\section{1. 緒}

空気圧を作動流体として位置決めをする場合，電動 機のような高速で微細な制御が困難である原因として はシール部分の摩擦力および空気の圧縮性による非線 形性などが挙げられる。

したがって，これまでの空気圧アクチュエータの位 置決め制御に関する研究論文は空気の圧縮性による非 線形性をどのように制御するか，また摩擦力の影響な どを如何に補償するかが重要な課題として取り扱われ てきた ${ }^{12)}$. その中でも摩擦力は空気圧シリンダの目標 值近傍での整定に大きな影響を与え, 位置決めの精度 を低下させることが知られている374.

そこで本研究ではシリンダとピストンを非接触の構 造にすることによって摩擦の影響を減少させ，位置決 めの精度が向上できるサーボテーブルを提案する.

このテーブルは通常のシリンダで用いられるピスト

\footnotetext{
*平成 8 年11月 13 日 原稿受付

**東京工業大学精密工学研究所

***京セラ(侏)

(所在地 ₹226 横浜市緑区長津田町4259)
}

ンシールを取り除く形となり, 外部加圧式の静圧機構 を取り入れてピストンをテーブル本体から浮上させる ことによりピストンがテーブルと非接触の形で駆動さ れる.このような空気静圧軸受けの働きによる空気膜 の介在により固体接触がない駆動方式が実現できるた め, ピストンが駆動される時の摩擦力の影響を限りな く零に近く減少することができる.さらに，浮上され たピストンを高速サーボ弁で駆動する構造になってお り, 純粋な空気圧機構による高速かつ高精度の位置決 めが可能となる.

本研究では提案したサーボテーブルおよび高速サー ボ弁を用い空気圧サーボシステムを構成して位置決め 実験を行い, サーボテーブルの位置決め精度および速 応性を検討した. その結果, 摩擦力を取り除いたサー ボテーブルを用いることにより空気圧サーボシステム の位置決め性能が著しく向上させることを確認した. 主な記号

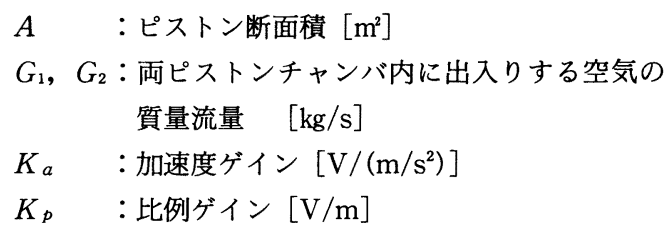


$K_{r} \quad$ : 速度ゲイン $[\mathrm{V} /(\mathrm{m} / \mathrm{s})]$

$M \quad$ : ピストン質量 $[\mathrm{kg}]$

$L \quad$ ：ピストンの全ストロク $[\mathrm{m}]$

$P_{b} \quad$ : 静圧機構用供給圧 $\left[\mathrm{N} / \mathrm{m}^{2}\right]$

$P_{0} \quad:$ ピストンチャンバ内の平行圧力 $\left[N / \mathrm{m}^{2}\right]$

$P_{S} \quad$ : ピストン駆動用供給圧 $\left[\mathrm{N} / \mathrm{m}^{2}\right]$

$R \quad$ : ガス $[\mathrm{J} /(\mathrm{kgK})]$

$s \quad$ : ラプラス演算子

u : コントローラ出力 $[\mathrm{V}]$

$\hat{u} \quad$ : サーボ弁の流量ゲインの線形化入力 $[\mathrm{V}]$

$x \quad$ : ピストン変位 $[\mathrm{m}]$

$\theta_{a} \quad$ 大気温度 $[\mathrm{K}]$

2. サーボシステムの構成

\section{1 サーボテーブルの構造}

Fig.1にサーボテーブルの構造を示す。(a)はサーボ テーブルの平面図，(b)は空気軸受け機構の概念図，(c) はサーボテーブル実物の写真，(d)はサーボテーブルを 横から見たところの断面図をそれぞれ示す。

Fig. 1の(a), (c), (d)から分かるように，ピストンは枠
状で，上から見るとII形になっており，断面は長方形 である。また，ピストンの側面はあるが上面と下面は ない. 枠状ピストンは上面の一部だけに穴が開いてい る枠状の本体に収まり，この穴を通じて(d)に示されて いるようにピストン上に負荷が乗せられる構造となっ ている.また，ピストンと本体の間ではFig. 1の(a)に示 されているように $V_{1}, V_{2}, V_{3}, V_{4}$ の四つの空間が形 成されており，ピストンがどの位置に移動しても，四 つの空間と本体上の穴は通じないように設計されてい る.さらに, 空間 $V_{2}$ と $V_{4}$ はチューブでつながっており, 自由に空気が往来できる。

ピストンはFig.1の(b)のように静圧の軸受け機構を 取り, 左右の側面の各端面および上下の各端面には浅 く長い溝がそれぞれ 4 本ずつ設けられている.

サーボテーブル中央から軸受け用圧力 $P_{b}$ を供給す ると, 空気が $V_{2}, V_{4}$ からピストンの端面に設けられて いる溝に流れ込, 圧力が低い $V_{1}, V_{3}$ に流れながら, 本 体の内壁面を押す力を発生する。このことにより，ピ ストンが本体の内壁面から離れて浮上する。このよう な静圧機構の働きによってピストンとテーブルが非接

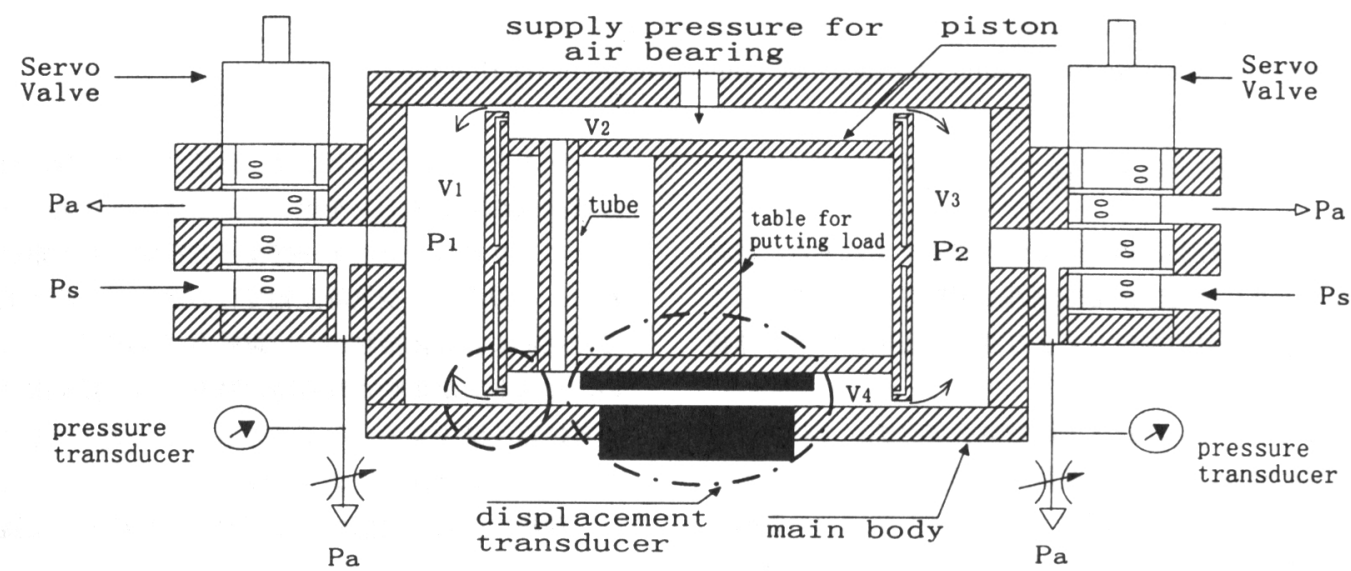

(a) Structure of the Servo Table

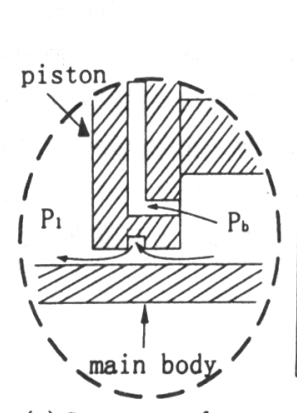

(b) Structure of Air Bearing

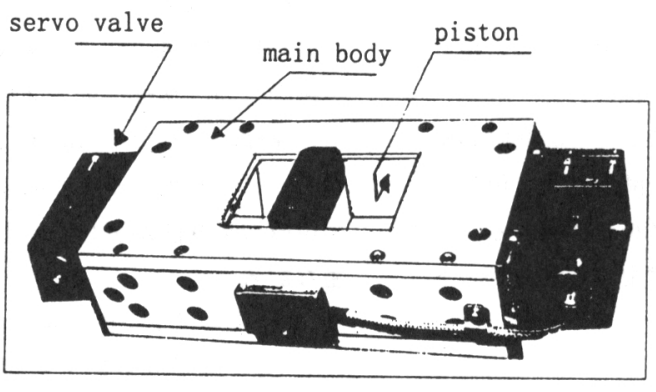

(c) Photograph of the Servo Table

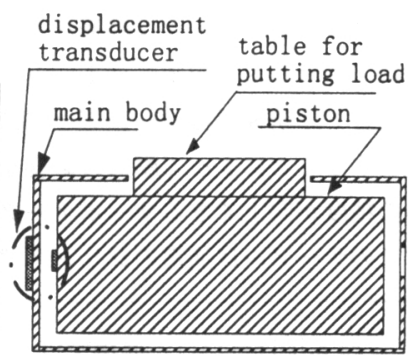

(d) Side View of the Servo Table

Fig. 1 Proposed Air Servo Table 
触の形で駆動され，目標値近傍で摩擦力の影響を受け ない形で位置決めができるため, 通常の空気圧シリン ダに比べて高精度の位置決めが期待される.

先の静圧機構により両ピストン室に流れ込む流量が 位置決め性能に与えられる影響を避けるため，テーブ ルの両側には可変絞りを設け, 静圧機構により発生す る流量をピストン室の外に放出する構造になっている. テーブルの加工精度を上げるため, かつ, ピストン の重さをできるだけ小さくし，固有振動数を高めるた めテーブルの材質はセラミックスを選定して製作した。 試作したサーボテーブルの寸法をTable. 1に示す.

コンパクト化されたピストン室の設計と相まって, 無負荷時に平衡点のテーブルの固有振動数は空気バ ネ・質量系として40 [HZ] 近くになっている.これは 従来の空気圧シリンダに比べて固有振動数が高く, 高 速と言える。

\section{2 サーボ弁およびセンサ}

変位センサには分解能20 $[\mu \mathrm{m}]$ のエンコーダ (ミツ トヨST211）を用い $1[\mu \mathrm{m}]$ まで20莪倍してデジタル カウンタで計測した。 また両ピストン室の圧力は分解 能 $0.3[\mathrm{kPa}]$ の半導体式圧力センサ（トヨダSD200） を用いて計測した。

また，配管による影響をさけるため 3 ポート形サー ボ弁 (コルベンバハEWS3/6) をテーブルの両側にそれ ぞれ直接取り付けた。この弁は50［\%] ストロークで $80[\mathrm{~Hz}], 100[\%]$ ストロークで60 [Hz] 近傍まで追 従する高速駆動形のサーボ弁である.このサーボ弁の 周波数特性をFig. 2に示す. 図の中で実線は入力のゲ インを弁への最大入力の $100[\%] ，$ 破線は50 [\%]に 設定した場合の実験結果であり， $u_{i n}$ はサーボ弁への入 力電圧, $u_{\text {out }}$ はスプールの変位を表す.

Fig. 3は入力電圧に対するサーボ弁の有効断面積を 示し, サーボ弁には約 3 [\%] 程度のヒステリシスが 存在していることが分かる.

\section{3 制御アルゴリズム}

提案したサーボシステムのモデルを単純化するため, つぎのように仮定する。

（1）サーボ弁は中立点近傍で作動し，中立点での空 気の漏れはない. また, 左右のサーボ弁の特性は 等しい.

Table. 1 Dimensions of the Servo Table

\begin{tabular}{|l|c|}
\hline stroke & $50[\mathrm{~mm}]$ \\
\hline piston area & $2.7 \times 10^{3}\left[\mathrm{~mm}^{2}\right]$ \\
\hline piston mass & $0.48[\mathrm{~kg}]$ \\
\hline
\end{tabular}

（2）サーボテーブルは左右対称である.

（3）静圧軸受け機構の働きにより摩擦力は存在しな い.

（4）ピストンチャンバ内には常に静圧軸受け機構用 の流量が流れ込むのでチャンバ内の熱移動が非常 に早くなる．したがって，チャンバ内の空気の温 度の変化は等温変化である。

仮定(1)により, 線形化されたサーボ弁の流量方程式 は次のようになる。

$$
G_{1}=k_{q} \hat{u}=-G_{2}
$$

ここで, $k_{q}=\partial G_{1} / \partial \hat{u}$ であり, サーボ弁の入力・質 量流量ゲインを表す。また，仮定(2)〜(4)により，サー

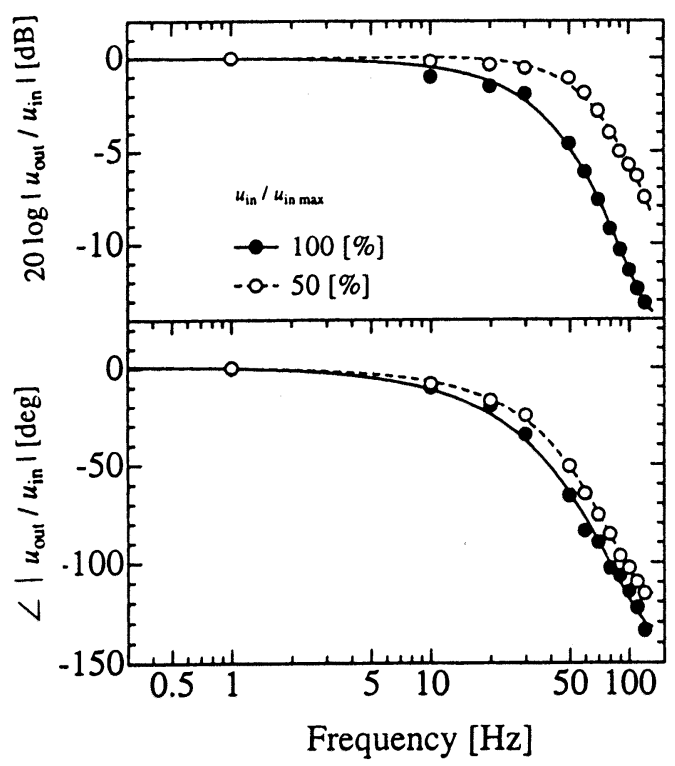

Fig. 2 Frequency Response of the Servo valve

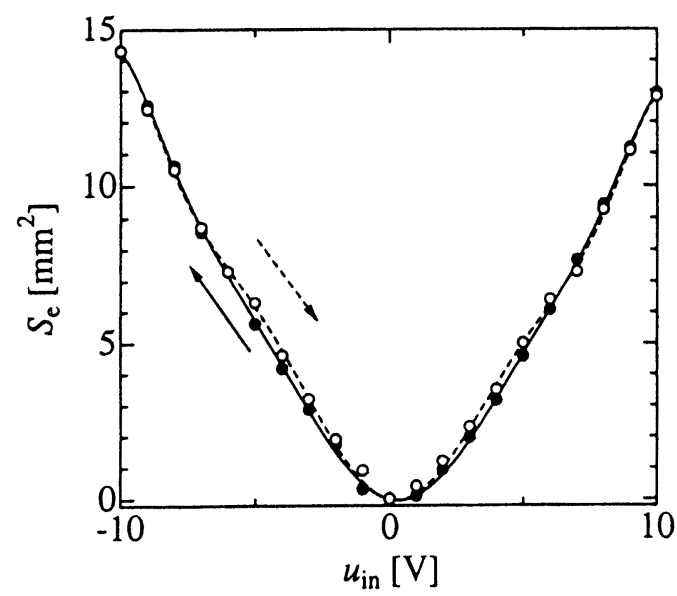

Fig. 3 Effective Area of the Servo Valve 
ボテーブルの両ピストンチャンバ内の圧力の変化およ びピストンの運動方程式は次のように表すことができ る.

$$
\begin{aligned}
& \frac{d P_{1}}{d t}=\frac{R \theta_{a}}{A x} k_{q} \hat{u}-\frac{P_{1}}{A x} \cdot v A \\
& \frac{d P_{2}}{d t}=-\frac{R \theta_{a}}{A(L-x)} k_{q} \hat{u}+\frac{P_{2}}{A(L-x)} \cdot v A \\
& M \frac{d^{2} x}{d t^{2}}=A\left(P_{1}-P_{2}\right)
\end{aligned}
$$

ここで, $P_{1}, P_{2}$ は両ピストンチャンバ内の圧力, $v$ は ピストンの移動速度を表す。

平衡点を $x=x_{0}, v=0, P_{1}=P_{2}=P_{0}$ とし, 式(2) (4) をテイラー展開により 1 次近似すると次のような状態 方程式で表すことができる.

$$
\frac{d}{d t}\left[\begin{array}{c}
x \\
v \\
P_{1} \\
P_{2}
\end{array}\right]=\left[\begin{array}{cccc}
0 & 1 & 0 & 0 \\
0 & 0 & \frac{A}{M} & -\frac{A}{M} \\
0 & -\frac{P_{0}}{x_{0}} & 0 & 0 \\
0 & \frac{P_{0}}{L-x_{0}} & 0 & 0
\end{array}\right]\left[\begin{array}{c}
x \\
v \\
P_{1} \\
P_{2}
\end{array}\right]+\left[\begin{array}{c}
0 \\
0 \\
\frac{k_{q} R \theta_{a}}{A x_{0}} \\
-\frac{k_{q} R \theta_{a}}{A\left(L-x_{0}\right)}
\end{array}\right] \hat{u}
$$$$
x=\left[\begin{array}{llll}
1 & 0 & 0 & 0
\end{array}\right]\left[\begin{array}{llll}
x & v & P_{1} & P_{2}
\end{array}\right]^{T}
$$

式(5)を用いてサーボ弁への入力からサーボテーブル の変位までの伝達関数を求めると次のようになる.

$$
\begin{aligned}
& \frac{x(s)}{\hat{U}(s)}=\frac{k_{n} \omega_{n}{ }^{2}}{s\left(s^{2}+\omega_{n}^{2}\right)} \\
こ こ て ゙, & k_{n}=\frac{k_{q} R \theta_{a}}{A P_{0}}, \quad \omega_{n}{ }^{2}=\frac{A P_{0} L}{M x_{0}\left(L-x_{0}\right)} \text { であり, } \omega_{n}
\end{aligned}
$$

はサーボ系の固有周波数を表す.

式(6)から分かるように，提案したサーボシステムは 静圧軸受け機構の働きにより, 隇衰特性が悪くなる. したがって, サーボ系全体の減衰特性を高めなければ, 高速な位置決め制御が実現できないことが予想される. このような場合, 位置の誤差, ピストンの速度および 加速度情報を用いて位置決め制御を行うことにより, 高速な制御が可能であることが知られている5

そのような制御則を用いた場合のコントローラの出 力は次のようになる.

$$
u=K_{p} \cdot\left(x_{r}-x\right)-K_{v} \cdot v-K_{a} \cdot a
$$

ここで, $x_{r}$ は目標位置, $a$ はピストンの加速度を表す. 式(7)の制御則を施した場合の目標位置からピストン変 位までの閉ループ伝達関数は次のようになる。

$$
\frac{x(s)}{x_{r}(s)}=\frac{k_{n} \omega_{n}^{2} K_{p}}{s^{3}+k_{n} \omega_{n}^{2} K_{a} s^{2}+\left(\omega_{n}^{2}+k_{n} \omega_{n}^{2} K_{v}\right) s+k_{n} \omega_{n}^{2} K_{p}}(8)
$$

速度および加速度情報は位置センサからの位置信号
を用いて求められるが，位置信号を数值微分する際， 完全な微分を実現することは不可能であるため，実際 には疑似微分 ${ }^{6}$ により求めることになる。速度および 加速度を 2 次遅れフィル夕を用いた擬似微分により求 めると次のような形で表すことができる.

$$
\begin{aligned}
& v(s) \cong \frac{\omega_{f}^{2}}{s^{2}+2 \xi \omega_{f} S+\omega_{f}^{2}} \cdot s x(s) \\
& a(s) \cong \frac{\omega_{f}^{2}}{s^{2}+2 \xi \omega_{f} s+\omega_{f}^{2}} \cdot s v(s)
\end{aligned}
$$

ここで, $\omega_{f}:$ フィルタの遮断周波数, $\xi:$ 隇衰比であ る.

したがって，変位センサの分解能および用いられる 速度, 加速度の周波数領域を考慮してローパスフィル 夕を設計することになるので速度および加速度情報の 位相遅れが生じる，通常の空気圧サーボの場合，この ような位相遅れが制御性に与える影響は少ないが，本 研究の場合には高速な位置決め制御を目的としている ため, 特に, 加速度情報の遅れが制御性に大きな影響 を与えることを確認した．そこで，加速度情報を用い る際には位相遅れを避けるため, 圧力センサの計測值 から加速度に算出した值を用いた。

制御ゲインは 3 次系コントローラ設計法のひとつで ある $\alpha-\beta$ 法 $^{7}$ を用いて決定した。 $\alpha$ - $\beta$ 法を用いる場合, 比例ゲインは閉ルプ系の動特性を考慮して決定し, 速 度および加速度ゲインは $\alpha-\beta$ 線図上の值を用い, 次式 により決定される。

$$
\begin{aligned}
& K_{v}=\left(\beta \cdot \sqrt{\left(k_{n} \omega_{n}^{2} K_{p}\right)^{2}}-\omega_{n}^{2}\right) /\left(k_{n} \omega_{n}^{2}\right) \\
& K_{a}=\left(\alpha \cdot \sqrt{\left(k_{n} \omega_{n}^{2} K_{p}\right)}\right) /\left(k_{n} \omega_{n}{ }^{2}\right)
\end{aligned}
$$

サーボ系全体のブロク線図をFig. 4示す.

Fig. 4の中で，破線で囲まれている部分はサーボ弁 の入力・流量ゲインの線形化を表すサーボ弁の入 力・流量ゲインを線形化する際にはFig. 3の入出力特 性を用い, サーボ弁への入力に対してサーボ弁のス プールの変位が線形になるように近似した線形化関数 を用いた。

コントローラにはマイコンを用い, 位置決め制御ア ルゴリズムをソフトウエアで実現した。

\section{3. 摩擦力の推定}

サーボテーブルの摩擦力を測定した結果をFig. 5に 示す. 今回, 製作したサーボテーブルはストロークが 短いので通常の測定法では摩擦力を測定することが困 難である。したがって, ピストンを適当に位置決めし その時の変位および圧力のデータを基にして摩擦力を 算出する方法を用いた。

Fig.5で一番上の図は位置決めした時のピストンの 


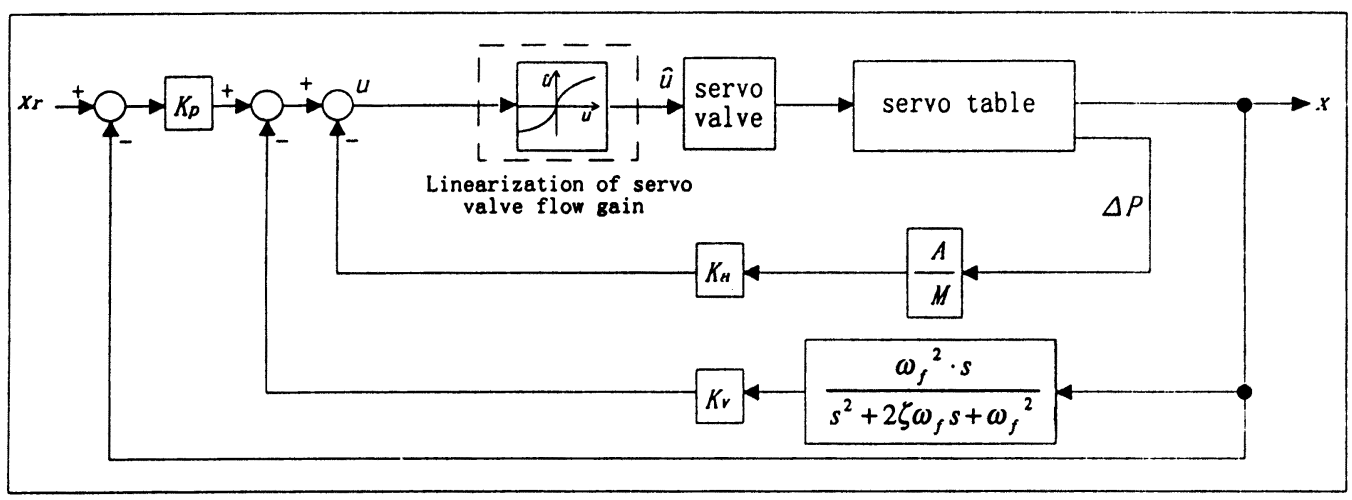

Fig. 4 Block Diagram of the Displacement Control System

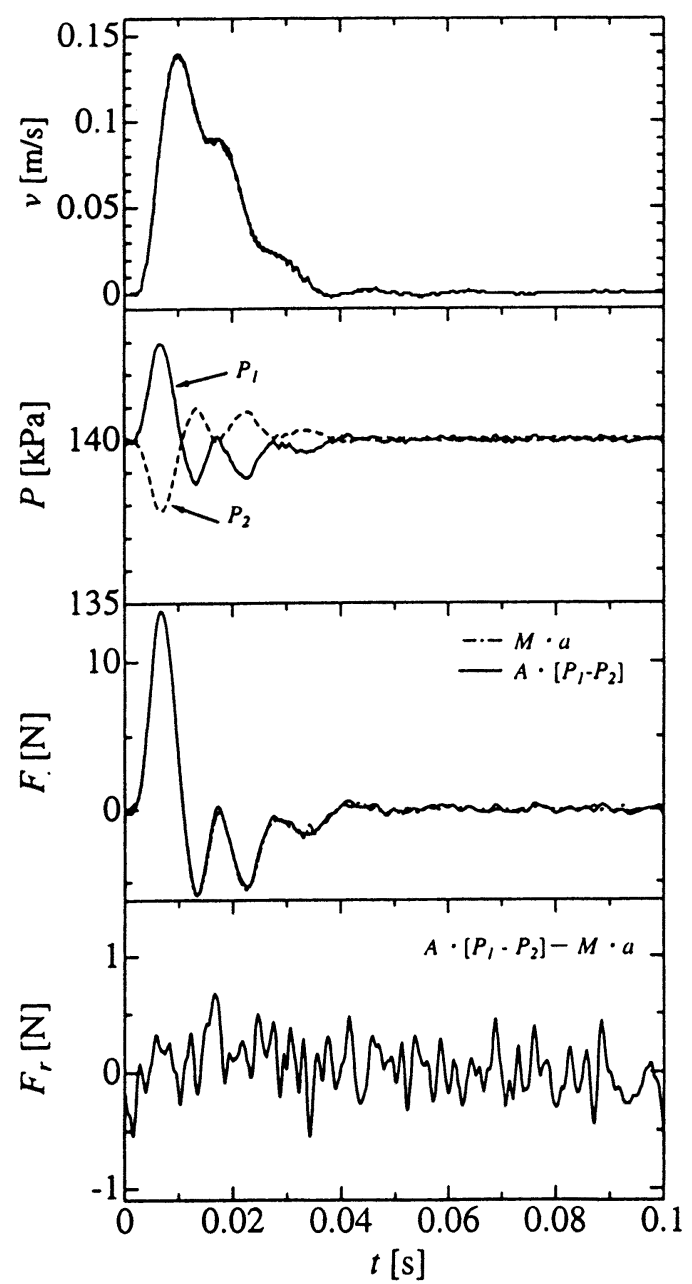

Fig. 5 Friction of the Servo Table

速度, 二番目の図は圧力の変化, 三番目の図はピスト ンの駆動力, 四番目の図は摩擦力を表す。三番目の図 の中で, 一点鎖線は変位を擬似微分して求めたピスト
ンの加速度により換算したピストンの駆動力 $(M \cdot a)$, 実線は圧力差から換算したピストンの駆動力 $(A$ ・ $\Delta P)$ をそれぞれ示す.

この結果で摩擦力 $(A \cdot \Delta P-M \cdot a)$ は全速度範囲に わたって0.5 [N] 以下であることが確認される. しか しながら, 今回用いた压力センサのノイズが 0.3 $[\mathrm{kPa}]$ 程度であることを考慮すると測定された摩擦力 が圧力センサのノイズ範囲以内の值であることが分か る.

また, 通常の 0 リングシールに比べ, 摩擦力が小さ いことが知られているラビリンスシール方式の空気圧 シリンダの摩擦力はおよそ $5[\mathrm{~N}]$ であることが報告さ れている7).したがって, 試作したサーボテーブルの摩 擦力の測定值は圧力センサのノイズを考慮しなくても ラビリンスシール方式の空気圧シリンダの摩擦力の約 1/10であることが分かる．この結果から，テーブルの 静圧軸受け機構が十分に働いており, 通常のシリンダ に比べて摩擦力が十分に小さいことが認められる.

\section{4. 実験 結果}

試作したサーボテーブルおよび高速サーボ弁を用い， 位置決め制御の実験を行った。その際の実験条件を Table. 2に示す. 実験の際のサンプリング時間は 0.06 [ms] とした.

\section{1 1 ステップ応答}

サーボテーブルのステップ応答をFig. 6に示す.こ の結果は目標ステップの幅を $2[\mathrm{~mm}]$ に設定し, $K_{p}=$ $7000, K_{v}=34, K_{a}=0.124$ とした場合の結果である.

Fig. 6の一番上の図はピストンの全体の動き，2番 目は目標值近傍での拡大図, 3 番目はピストンの加速 度, 4 番目はコントローラからの出力, 5 番目はその 時の両シリンダ室内の圧力の変化をそれぞれ示す.

図から $\pm 10[\mu \mathrm{m}]$ の誤差範囲に収束していることが 
Table. 2 Supply Pressure and Leakage Flowrate. through Air Bearing Structure

\begin{tabular}{|l|c|}
\hline $\begin{array}{l}\text { supply pressure for driv- } \\
\text { ing piston }\left(\mathrm{P}_{\mathrm{s}}\right)\end{array}$ & $160[\mathrm{kPa}]$ \\
\hline $\begin{array}{l}\text { supply pressure for air } \\
\text { bearing }\left(\mathrm{P}_{\mathrm{b}}\right)\end{array}$ & $200[\mathrm{kPa}]$ \\
\hline $\begin{array}{l}\text { initial pressure in piston } \\
\text { chamber }\end{array}$ & $140[\mathrm{kPa}]$ \\
\hline $\begin{array}{l}\text { leakage flow-rate from } \\
\mathrm{P}_{\mathrm{b}} \text { to piston chamber }\end{array}$ & $1.4 \times 10^{-9}\left[\mathrm{~m}^{3} / \mathrm{s}\right]$ \\
\hline
\end{tabular}

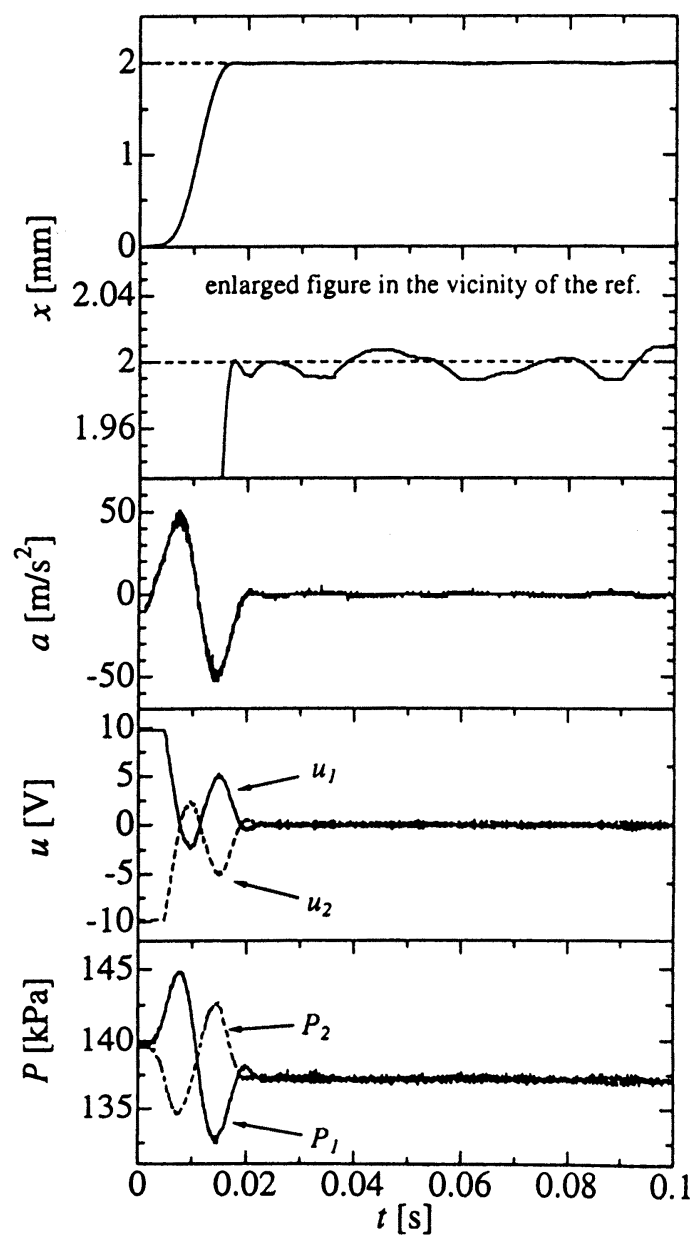

Fig. 6 Displacement Control Results (reference: $2[\mathrm{~mm}]$ )

分かる. また，位置決め時のピストンの最大加速度は 約 $50\left[\mathrm{~m} / \mathrm{s}^{2}\right]$ であり, 約 $16[\mathrm{~ms}]$ で土10 [ $\left.\mu \mathrm{m}\right]$ の誤差 範囲に整定し，非常に速い動作が実現できた。

位置決めの結果から変位の立ち上がりで $4[\mathrm{~ms}]$ 程
度のむだ時間が見える.このことは最初の $2[\mathrm{~ms}]$ の 間はコントローラからの出力があるのにもかかわらず 圧力が変化しておらず，サーボ弁の遅れが原因である ことがわかる. 残り $2[\mathrm{~ms}]$ は圧力により加速されて いるものの変位として表れないので慣性によるピスト ンの遅れが原因であると思われる。

目標值近傍での拡大図を考察すると目標值近傍で微 妙に振動しながらピストンが動いている様子が見られ る.この振動はフィードバックの効果がなく自由振動 的な挙動を示している.これは今回用いた圧力センサ のノイズが $0.3[\mathrm{kPa}]$ 程度存在するため, $0[\mathrm{~V}]$ 近 傍でのコントローラの出力は压力センサのノイズによ る加速度ゲインからの出力によって支配され適切な加 速度情報がフィードバックされないこと，また，サー ボ弁のヒステリシスが 3 [\%] 程度存在するためサー ボ弁への入力電圧がこのヒステリシス範囲に近いこと などが原因であると考えられる。

\section{2 周波数応答}

Fig. 7, Fig.8はサーボ系全体の閉ループ周波数応 答を示す. 実験の場合, 振幅は $2[\mathrm{~mm}]$ で, コント ローラのゲインはFig. 6の場合と同じく設定した.

Fig. 7の(a)は入力を $1[\mathrm{~Hz}]$ に設定した場合，(b)は 入力を $50[\mathrm{~Hz}]$ に設定した場合のピストンの変位をそ れぞれ示す．静圧軸受け機構の働きにより摩擦力が低 減され，高周波の場合だけでなく低周波数の場合にも

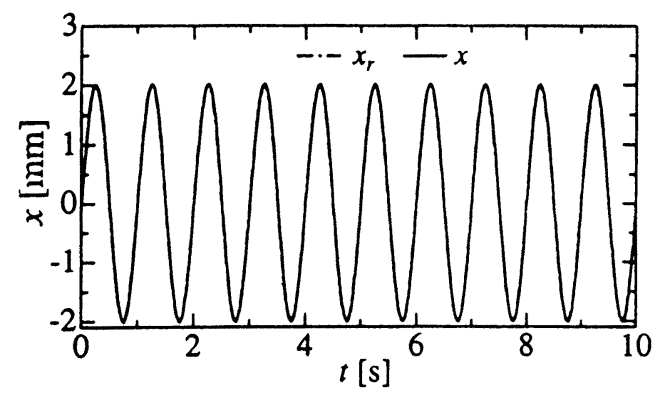

(a) in case of $1[\mathrm{~Hz}]$

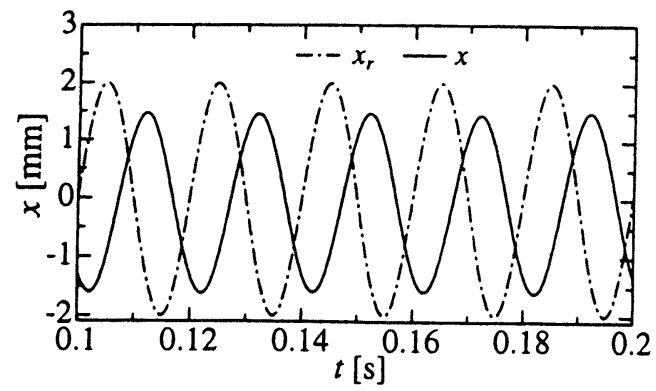

(b) in case of $50 \quad[\mathrm{~Hz}]$

Fig. 7 Frequency Response of the Servo System I 


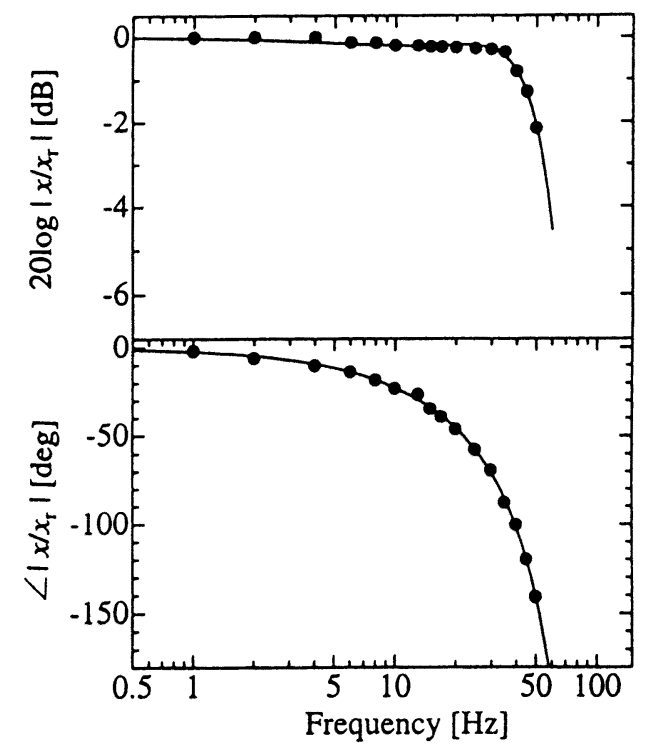

Fig. 8 Frequency Response of the Servo System II

Table. 3 Performance of displacement control

\begin{tabular}{|l|c|}
\hline reference & $2[\mathrm{~mm}]$ \\
\hline settling time & $16[\mathrm{~ms}]$ \\
\hline positioning accuracy & $\pm 10[\mu \mathrm{m}]$ \\
\hline $\begin{array}{l}\text { band-width of frequency } \\
\text { response }\end{array}$ & $50[\mathrm{~Hz}]$ \\
\hline
\end{tabular}

ピストンが目標値によく追従していることが分かる.

Fig. 8 は $50[\mathrm{~Hz}]$ までの周波数応答をまとめた結果 であり，上の図はゲインを，下の図は位相を示す。

結果から系のバンド幅は約50 [Hz] であり，これま での空気圧位置サーボ系に比べてかなり高い周波数領 域まで追従していることがわかる.また, Fig. 20サー ボ弁の周波数応答と比較してみるとサーボ弁への入力 を100 [\%]に設定した場合の周波数応答と近い結果が 得られていることが分かる.

\section{5.まと め}

本研究では空気圧システムを用い位置決めをする際,
位置決めの性能を悪化させる重要な原因のひとつであ る摩擦の影響を無くすため, 静圧軸受け機構を取り入 れた新しいサーボテーブルを試作した。また，この テーブルと高速サーボ弁を用い位置サーボ系を構成す ることにより，ミクロン単位の精密かつ高速な位置決 め制御ができることを確認した。

本研究で得られた結果を表 3 に示す. 表 3 の中で整 定時間は土10 $[\mu \mathrm{m}]$ の誤差範囲に収束した時の時間を 表す.

\section{参 考 文 献}

1) 中野：空気圧・圧電超音波複合形アクチュエー夕 による精密位置決めシステム, 油圧と空気圧, 24 - 3, 394/398 (1993)

2 ) 高岩, 則次 : 外乱オブザーバを用いた空気圧シリ ンダの位置決め制御，計測自動制御学会論文集, 31-1，82/88 (1995)

3 ) 河合, 増田 : 空気圧シリンダの高速位置决め制御 に関する考察, 秋季油空圧講演会講演論文集, 73/76 (1992)

4 ) 斉藤：空気圧シリンダの低速度制御に関する研究, 油圧と空気圧，26-6，804/810（1995）

5) P R Moore: Compensation in pneumatically actuated servomechanisms, Trans Inst M C, Vol 7, No 5, Oct-Dec, 238/244 (1985)

6 ） システム制御情報学会編：PID制御，47/48 (1995)

7 ) 花房 : 関節形ロボットの制御を目的とした電気油 圧サーボ系の設計, 油圧と空気圧，13-7，429/ 436 (1982)

8 ) 川嶋：空気圧シリンダのミクロンオーダーの位置 決め, 油圧と空気圧, 24-7,755/761（1993）

9 ) 小山：高応答電磁弁を使った空気圧シリンダの高 精度位置決め, 油圧と空気圧，20-6，525/530 (1989) 